\title{
ИЗОТОПНЫЙ СОСТАВ УГЛЕРОДА НЕКОТОРЫХ САПРОПЕЛИТОВ КАК ПОКАЗАТЕЛЬ ИХ ФОРМИРОВАНИЯ
}

Со времени появления основополагающих работ Х. Крейга и А. О. Нира о стабильных изотопах углерода в геохимии $\left[{ }^{1,2}\right]$ проделана огромная работа в области исследования закономерностей распределения углеродных изотопов в различных природных объектах, а также процессов, приводящих к их разделению.

В литературных источниках широко освещены вопросы фракционирования изотопов углерода в нефти $\left[{ }^{3-5}\right]$. Показано, что изотопный состав углерода нефти близок к составу углерода органического вещества растительного и животного происхождения, что существует различие в изотопном составе углерода нефти, залегающей в морских и континентальных отложениях [6], что углерод нефти изотопически тяжелее углерода природных газов.

В ряде публикаций приведены данные об исследовании фракционирования углеродных изотопов в природных газах $\left[{ }^{6-8}\right]$. Доказано, что газы бактериального происхождения по изотопному составу образуют обособленную группу, характеризующуюся высоким содержанием легкого изотопа ${ }^{12} \mathrm{C}$ по сравнению с газами нефтегазовых месторождений и магматических газопроявлений.

Исследование изотопного состава углерода в природном органическом веществе позволяет решать вопросы генезиса осадочных пород, нефтяных и газовых месторождений, вопросы образования геохимических аномалий, миграции углеводородов [ $\left.{ }^{9-12}\right]$.

В настоящей работе изучался изотопный состав углерода сапропелевых горючих сланцев. Задача нашего исследования состояла в выяснении связи между изотопным составом углерода в органическом материале сланцев и его фациально-генетическим типом с целью получения вывода об условиях формирования.

\section{Характеристика сланцев и примененных методов исследования}

Исследованию подвергались следующие сапропелиты:

I - чаганский сланец Оренбургского района, юрского возраста, морского происхождения, органическая часть представлена бесструктурным гумусово-сапропелитовым веществом, отличается высоким содержанием серы $\left[{ }^{17}\right]$;

II - горючий сланец Борова Дола Сливенского округа Болгарской НР, составляет часть молассоидно-каустобиолитовой формации верхнеэоценового возраста, фациальный тип озерный с морским влиянием $\left[{ }^{18}\right]$; 
Таблица 1

Характеристика исходных сланцев

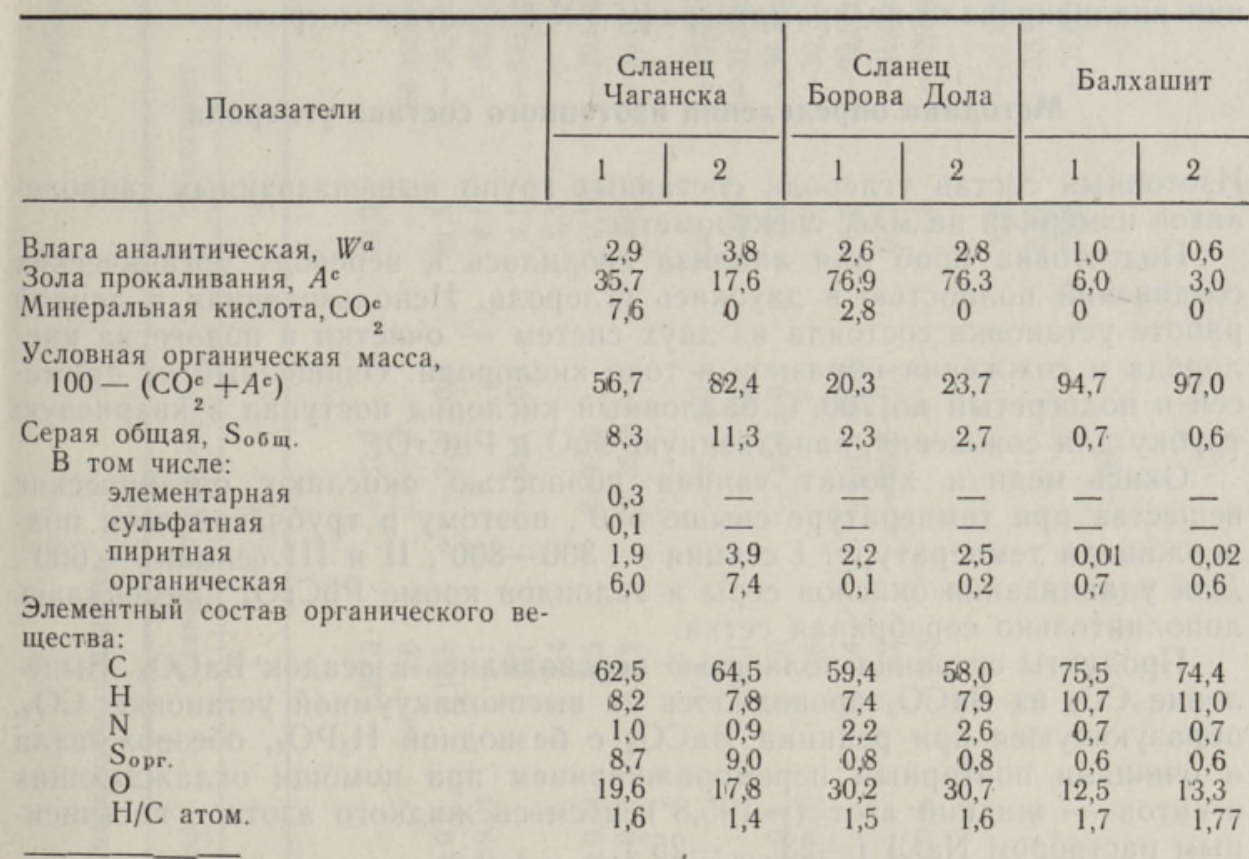

Пр и меч ан и е: 1 - исходный сланец, 2 - дебитуминизированный сланец.

III - балхашит залива Алакуль озера Балхаш, современного происхождения, образуется из маслосодержащей водоросли Botriococcus Braunii [ $\left.{ }^{19}\right]$.

Сапропелиты исследовались по комплексной схеме, сочетающей деструктивные, хроматографические и спектрометрические методы. В измельченных пробах определяли содержание влаги, серы и т. д. Результаты анализов приведены в табл. 1 .

Из высушенных измельченных проб сланцев экстрагировали хлороформом битумоид А, остаток обрабатывали $10 \%$-ной $\mathrm{HCl}$ и после промывки и высушивания из него экстрагировали смесью метанол : бензол (1:3) битумоид С.

В дебитуминизированных пробах определяли содержание минеральной части и органического вещества, а также элементный состав последнего (см. табл. 1). Характеристики сланцев в ходе экстракции существенно не изменились. Выходы битумоидов на условную органическую массу были следующими (в \%): чаганский сланец - битумоид А $-1,1$; битумоид C $-0,8$; сланец Борова Дола: $\mathrm{A}-2,1, \mathrm{C}-$ 5,$2 ;$ балхашит A $-8,1 ; \mathrm{C}-5,4$.

Кислоты извлекали из битумоидов 0,5 н. спиртовым раствором КОН. Нейтральные компоненты экстрагировали из сухого остатка диэтиловым эфиром. Дебитуминизированную часть сланцев подвергали полукоксованию в стандартных условиях (ГОСТ 3168-66) в лабораторной алюминиевой реторте. Групповой химический состав суммарной смолы полукоксования определяли методом тонкослойной хроматографии $\left[{ }^{20}\right]$ на силикагеле Л 40/100, элюент $\boldsymbol{н}$-гексан. Фенолы выделяли двукратным избытком $10 \%$-ного водного раствора $\mathrm{NaOH}$.

2 ENSV TA Toimetised. K 21981 
Индивидуальный состав структурных групп битумоидов и смолы определяли газохроматографически на «Хром-4». Газы полукоксования анализировали на хроматографе УХ-1 с катарометром.

\section{Методика определения изотопного состава углерода}

Изотопный состав углерода составных групп вышеназванных сапропелитов измеряли на масс-спектрометре.

Подготовка проб для анализа сводилась к переводу органических соединений полностью в двуокись углерода. Использованная в данной работе установка состояла из двух систем - очистки и подогрева кислорода и сожжения образцов в токе кислорода. Очищенный от примесей и подогретый до $700^{\circ} \mathrm{C}$ баллонный кислород поступал в кварцевую трубку для сожжения, заполненную $\mathrm{CuO}$ и $\mathrm{PbCrO}_{4}$.

Окись меди и хромат свинца полностью окисляют органические вещества при температуре свыше $550^{\circ}$, поэтому в трубчатой печи поддерживали температуру: I секция $-300-800^{\circ}$, II и III секции $-600^{\circ}$. Для улавливания окислов серы и галоидов кроме $\mathrm{PbCrO}_{4}$ применялась дополнительно серебряная сетка.

Продукты сгорания полностью переводились в осадок $\mathrm{BaCO}_{3}$. Выделение $\mathrm{CO}_{2}$ из $\mathrm{BaCO}_{3}$ проводилось на высоковакуумной установке. $\mathrm{CO}_{2}$, образующуюся при реакции $\mathrm{BaCO}_{3}$ с безводной $\mathrm{H}_{3} \mathrm{PO}_{4}$, обезвоживали и очищали повторным перемораживанием при помощи охлаждающих агентов - жидкий азот $\left(-195,8^{\circ}\right)$ и смесь жидкого азота с насыщенным раствором $\mathrm{NaCl}\left(-23 \ldots-25^{\circ}\right)$.

Разделение газов полукоксования на составные группы проводилось на газовом анализаторе ТХЛ-1. Содержащаяся в газе $\mathrm{CO}_{2}$ поглощалась при повторном пропускании газа через барботер с 0,05 н. раствором $\mathrm{Ba}(\mathrm{OH})_{2}$. Затем система переключалась таким образом, что газ проходил через трубку сжигания (наполненную $\mathrm{CuO}$ ) при температуре $200^{\circ}$ и окись углерода окислялась до $\mathrm{CO}_{2}$. Аналогично окисляли при $800^{\circ} \mathrm{CH}_{4}$ и другие углеводороды. Последующая обработка образующейся $\mathrm{CO}_{2}$ описана выше. Очищенная $\mathrm{CO}_{2}$ вымораживалась жидким азотом в ампулы, которые поступали на масс-спектрометр МИ-1201. Результаты получены относительным компенсационным методом и представлены в виде промильных значений величины

$$
\delta=\frac{{ }^{13} \mathrm{C} /{ }^{12} \mathrm{C}_{\text {обр. }}-{ }^{13} \mathrm{C} /{ }^{12} \mathrm{C}_{\text {әтал. }}}{{ }^{13} \mathrm{C} /{ }^{12} \mathrm{C}_{\text {этал. }}} 1000 .
$$

Лабораторным эталоном служил активированный уголь, поправочный коэффициент которого по отношению к чикагскому стандарту РДВ равен - 25\%. Результаты измерений приведены в табл. 2.

Bce данные пересчитаны с учетом стандарта РДВ $\left({ }^{12} \mathrm{C} /{ }^{13} \mathrm{C}=88,99\right)$. Отрицательные значения $\delta$ указывают на то, что образцы легче чем предусмотрено стандартом, т. е. содержат меньше ${ }^{13} \mathrm{C}$.

\section{Обсуждение результатов и выводы}

При сравнении значений $\delta{ }^{13} \mathrm{C}$ исходных сланцев (табл. 2) бросается в глаза, что, несмотря на некоторые колебания, содержание ${ }^{13} \mathrm{C}$ уменьшается в ряду: чаганский сланец (I) $>$ сланец Борова Дола (II) $>$ $>$ балхашит (III), оставаясь однако в пределах, известных по литературным данным [13-16]. 


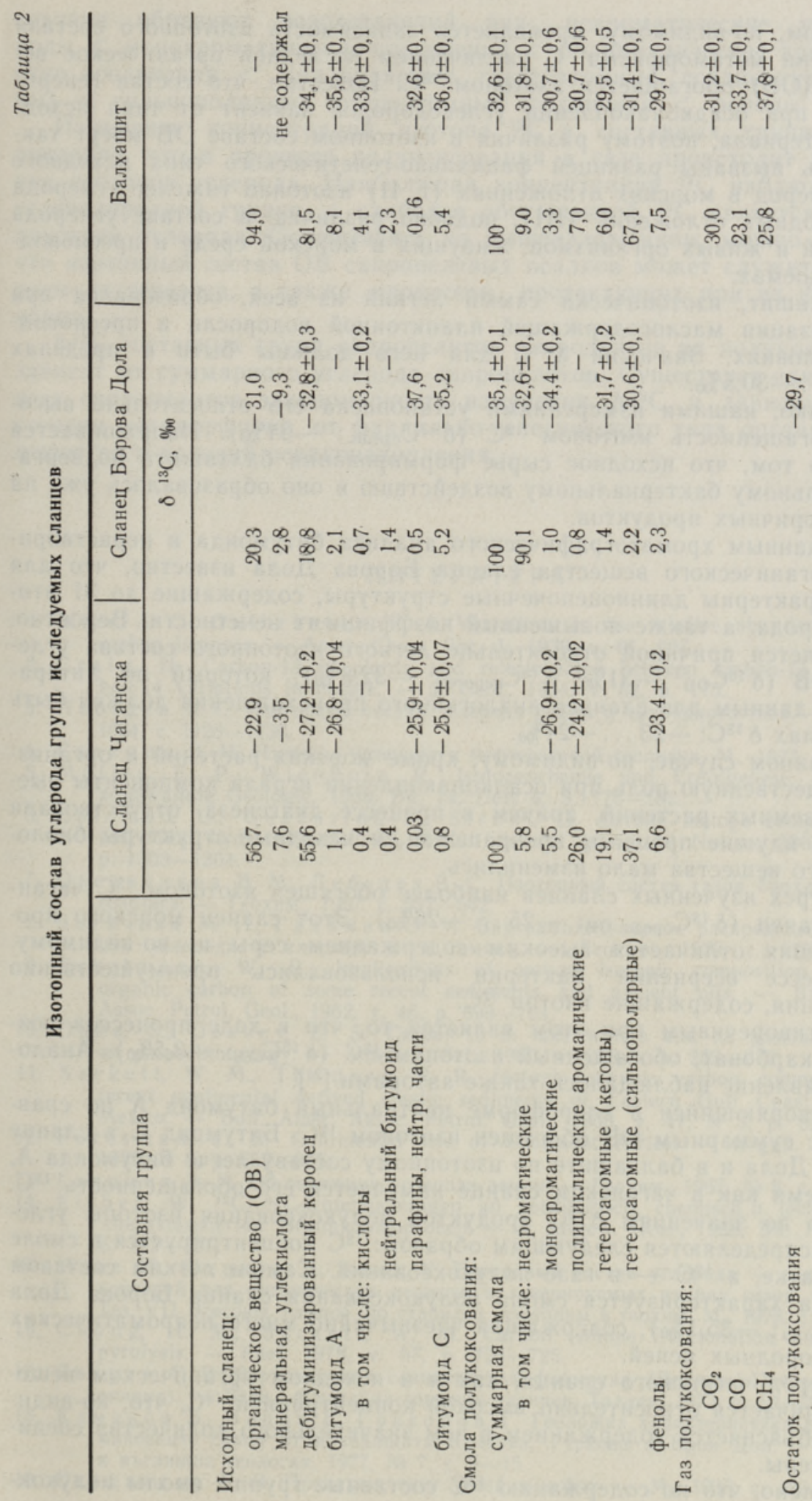


В этом, по-видимому, проявляется зависимость изотопного состава от степени метаморфизма. С увеличением последней органическое вещество (OB) обогащается изотопом ${ }^{13} \mathrm{C}$. Известно, что состав генерируемых при осадконакоплении углеводородов зависит от типа исходного материала, поэтому различия в изотопном составе ОВ могут также быть вызваны разницей фациально-генетического типа исходного ОВ. Углерод в морских отложениях (I, II) изотопно тяжелее углерода пресноводных отложений (III), подобно различию в составе углерода растений и живых организмов, живущих в морской среде и пресноводных водоемах.

Балхашит, изотопически самый легкий из всех, образовался при фоссилизации маслосодержащей планктонной водоросли в пресноводных условиях. Значения $\delta{ }^{13} \mathrm{C}$ для него должны быть в пределах $-26,9 \ldots-30,5 \%$.

Однако, нашими измерениями установлена его относительно высокая обогащенность изотопом ${ }^{12} \mathrm{C}\left(\delta^{13} \mathrm{C}_{\text {средн. }}-34 \%\right)$. Напрашивается вывод о том, что исходное сырье формирования балхашита подвергалось сильному бактериальному воздействию и оно образовалось уже на базе вторичных продуктов.

По данным хроматографического анализа битумоида и нерастворимого органического вещества сланца Борова Дола известно, что для него характерны длинноцепочечные структуры, содержащие до 31 атома углерода, а также повышенный коэффициент нечетности. Вероятно, это является причиной относительно легкого изотопного состава углерода ОВ $\left(\delta^{13} \mathrm{C}_{\mathrm{OB}}:-31 \%, \delta{ }^{13} \mathrm{C}_{\text {кероген: }}-32,8 \% 0\right)$, который по литературным данным для сланцев аналогичного происхождения должен быть в пределах $\delta{ }^{13} \mathrm{C}:-23 \ldots-24 \%$.

В данном случае, по-видимому, кроме морских растений и организмов существенную роль при осадконакоплении играли компоненты высших наземных растений, причем в процессе диагенеза отсутствовали глубоко идущие процессы превращения, и исходные структуры биологического вещества мало изменились.

Из трех изученных сланцев наиболее обогащен изотопом ${ }^{13} \mathrm{C}$ чаган-

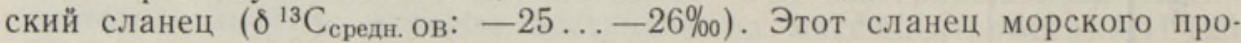
исхождения отличается высоким содержанием серы и, по-видимому, в процессе осернения бактерии использовались преимущественно соединения, содержащие изотоп ${ }^{12} \mathrm{C}$.

Противоречивым при этом является то, что в ходе процессов возникает карбонат, обогащенный изотопом ${ }^{13} \mathrm{C}\left(\delta^{13} \mathrm{C}_{\mathrm{CO}_{2}}:-3,5 \% 0\right)$. Аналогичное явление наблюдалось также авторами [리.

Растворяющийся в хлороформе нейтральный битумоид А по сравнению с суммарным ОВ обогащен изотопом ${ }^{12} \mathrm{C}$. Битумоид С в сланце Борова Дола и в балхашите по изотопному составу легче битумоида А, в то время как в чаганском сланце намечается его обогащенность ${ }^{13} \mathrm{C}$.

Судя по значениям $\delta{ }^{i 3} \mathrm{C}$ продуктов полукоксования изотопы углерода распределяются следующим образом: ${ }^{13} \mathrm{C}$ концентрируется в смоле и в остатке, a ${ }^{12} \mathrm{C}-$ в газе полукоксования. Самым легким составом углерода характеризуется смола полукоксования сланца Борова Дола $\left(\delta^{13} \mathrm{C}_{\text {смола: }}-35,1 \%\right)$, содержащая чрезвычайно много неароматических углеводородных цепей.

Углерод чаганского сланца, как и в исходном органическом веществе отличается относительно высокой концентрацией ${ }^{13} \mathrm{C}$, что, по-видимому, объясняется содержанием в нем значительного количества соединений серы.

Найдено, что по содержанию ${ }^{13} \mathrm{C}$ составные группы смолы полукок- 
сования образуют возрастающий ряд: неароматические углеводороды < моноароматические соединения < полициклические ароматические соединения < малополярные гетероатомные соединения (кетоны) < сильнополярные гетероатомные соединения < фенолы.

Измерение концентраций изотопа ${ }^{13} \mathrm{C}$ в составных группах газа показало, что в процессе полукоксования в газе происходит разделение изотопов углерода. Наибольшая концентрация ${ }^{12} \mathrm{C}$ наблюдается в углеводородной группе, а наиболее обогащенной ${ }^{13} \mathrm{C}$ является группа двуокиси углерода. Основываясь на вышеизложенном, можно сказать, что изотопный состав ОВ сапропелевых осадков может служить критерием их генезиса, а также процессов, протекающих при их формировании.

$\delta{ }^{13} \mathrm{C}$ составных групп сапропелитов и продуктов их полукоксования зависит от суммарного углерода сапропелитов. Существует единая для всех сапропелитов закономерность изменения $\delta{ }^{13} \mathrm{C}$ в зависимости от степени метаморфизма, от фациально-генетического типа органического вещества и условий осадконакопления.

\section{Л ИТ Р Р А У Р А}

1. Nier, A. O., Gulbransen, E. A. Variations in the relative abundance of the carbon isotopes. - Amer. Chem. Soc. J., 1939, v. 61, 697.

2. $\mathrm{Craig}, \mathrm{H}$. Carbon-13 in plants and relationships between carbon-13 and carbon-14 variations in nature, - J. Geol., 1954, v. 62, p. 115.

3. Л ебеде в В. С. Изотопный состав углерода нефти и природного газа. - Геохим. 1964 , c. $1128-1136$.

4. Г а ли м о в Э. М. Изотопы углерода в нефтегазовой геологии. М., 1973.

5. Müller, E. P., Wienholz, R. Isotopenchemie und Erdölgenese. - Z. für angewandte Geologie, 1968, Bd. 14, Heit 4, S. 176-182.

6. Colombo, U., Gazzarini, F., Sironi, G. Carbon isotope composition of individual hydrocarbons from Italian natural gases. - Nature, 1965, v. 205, p. $1303-1304$.

7. О в с янни иов В. М., Л е беде в В. С. Изотопный состав газов биохимического генезиса. - Геохим., 1967, с. $537-542$.

8. Богач е в а М. П., Г а ли м о В Э. М. Внутримолекулярное распределение изотопов углерода в хлорофилле и гемине. - Геохим., 1979, с. 1263-1271.

9. Eckelmann, W. R. Implications of carbon isotopic composition of total organic carbon of some recent sediments and ancient oils. - Bull. Amer. Assoc. Petrol. Geol., 1962, v. 46, p. 699-704.

10. O a na, S., Deevey, E. S. Carbon-13 in lake waters and its possible bearing on palaeolimnology. - Amer. J. Sci., 1960, v. 258-A, p. 253-272.

11. Sackett, W. M., Thom son, R. R. Isotopic organic carbon composition of recent continental derived clastic sediments of Eastern Gulf Coast, Gulf of Mexico. - Bull. Amer. Assoc. Petrol. Geol., 1963, v. 47, N 3, p. 525-531.

12. Foresman, J. B. Continental rise of Southeast Africa. - Organ. Geochem., 1979, N 8, p. $557-667$.

13. Га лим о в Э. М. Об эволюции углерода земли. - Геохим., 1957 , № 5 , с. $530-535$.

14. Fish er, W. ${ }^{12} \mathrm{C},{ }^{13} \mathrm{C}$-Untersuchungen an petrologisch, chemisch u. technologisch charakterisierten Braunkohlenproben. - Z. Angew. Geol,, 1968, Bd. 14, Heft 4, S. $182-187$.

15. М а а с И., Ш траух Г., В анд У. Изотопный состав углерода - генетический критерий для органических веществ и генерируемых из них газов. - В кн.: Tез. VII Всесоюз. симпоз. по стабильн. изотопам в геохим. М., 1978, с. $264-265$.

16. Chung, H. M., S a ckett, W. M. Carbon isotope fractionation during coal pyrolysis. - Fuel, 1978, v. 57, p. $724-725$.

17. Я в хута Г. В. Верхнеюрская сланценосная формация (Волжско-Печорская провинция). - В кн.: Формащии горючих сланцев. Таллин, 1973, с. 53-70.

18. Каменов Б., Панов Г., Гри горов Г. Геоложка характеристика а на битуминозните скали от находищата Красава, Гурково и Бров Дол. - Нефтена и въглищна геология, 1977 , № 7 , с. $5-15$.

19. С тадников Г. Л. Происхождение углей и нефти. - M., 1937 , с. $100-111$, 
20. Klesment, I. Application of chromatographic methods in biogeochemical investigations. - J. Chromatogr., 1974, v. 91, N 2, p. 705-713.

21. В и ногр адов А. П. и др. Изотопный состав серы и углерода в руде месторождения Шор-Су. - Геохим. 1964, № 11, с. 1075-1085.

Институт химии и

Ннститут геологии

Академии наук Эстонской ССР

Поступила в редакцию 5/IX 1980

Sibylle MUELLER, I. KLESMENT,

J.-M. PUNNING, R. VAIKMAE

\section{MONEDE SAPROPELIITIDE SUSINIKU ISOTOOPKOOSTIS NENDE TEKKE ISELOOMUSTAJANA}

Tšaganski ja Borov Doli pōlevkivi ning balhašiidi süsiniku isotoopkoostise alusel on esitatud järeldus, et esimene ja viimane on moodustunud vetikatest ning allunud tugevale bakteriaalsele töötlusele, kuna Borov Doli põlevkivi lähteaine on peamiselt maismaataimed.

Sibylle MUELLER, I. KLESMENT,

J.-M. PUNNING, R. VAIKMAE

\section{CARBON ISOTOPE COMPOSITION OF SOME SAPROPELITES AS A CHARACTERISTIC OF THEIR FORMATION}

Oil shales of the deposits of Tshagansk and Borov Dol and also of balhashite were investigated.

On the basis of the carbon isotope composition it is assumed that the original biological organic matter was bacteriologically transformed by the formation of the Tshagansk oil shale and balhashite. 